\title{
State of forest regeneration in Southwest Nigeria
}

\author{
O. I. Faleyimu ${ }^{1 *}$, B. O. Agbeja $^{2}$ and O. Akinyemi ${ }^{1}$ \\ ${ }^{1}$ Federal College of Forestry Mechanization, Afaka, Kaduna, Nigeria. \\ ${ }^{2}$ Department of Forest Resources Management, University of Ibadan, Ibadan, Oyo Sate, Nigeria.
}

Accepted 13 August, 2010

\begin{abstract}
The study investigated the state of forest regeneration in southwest Nigeria forest service. Secondary data were collected from the state forestry departments in South-Western Nigeria. The information was based on the forest regeneration between 1988 and 2004 as stipulated in the national forest policy of 1988. The study revealed that there were a total of 1619.19 ha of forest regeneration between 1988 and 2004 in south-west Nigeria. The largest was in Oyo State with an area of 6745 ha, followed by Ondo State with 4910.27 ha. Others were Ogun State (2700 ha), Ekiti State (1456 ha), Lagos State (656 ha) and the least was in Osun State with $\mathbf{4 8 1}$ ha. In this regards, unless there is regeneration and sustained yield to equate harvest, the depletion rates of the forest are bound to continue with adverse consequences on the environment.
\end{abstract}

Key words: Forest regeneration, forest policy, forest management.

\section{INTRODUCTION}

Literature is replete with overwhelming evidence of the significance of forests to human existence. Diouf (1997) asserted that forests are the most important terrestrial gene banks on earth. Forests are nature's bountiful and versatile renewable resources and are an integral part of the environment in which we live. The relationship between man and forests has always changed with socio-economic development, and will certainly continue to change. Establishment of forest policy is fundamental since it sets the framework in which all forestry activities in the country must be carried out. The most important of the forestry activities affected by a country's forest policy may be categorized as: (1) conservation, protection, administration, management and utilization of forests; (2) environmental protection and (3) forest industries and marketing of forest products. However, it must be emphasized that the ultimate purpose of a forest policy is to benefit the society and not trees, land or products. According to Adeyoju (1991), the ideal situation would be to have a formal document covering all aspects of the country's forest policy. This utopian situation is rarely, if ever, achieved.

The more usual case is that certain elements of a country's forest policy may be formally declared in a written document while other elements may have to be interpreted from legislation, plans and programmes. Adeyoju (2001) pointed out that there are 2 important aspects of plantation development. The first arises from the rather large and varied investments that have been committed to the schemes while the other pertains to the use of which the created resources (wood) have been put.

Long before independence in 1960, there was growing awareness of the inadequacies of natural regeneration techniques to fulfill the wood requirements of the rapidly increasing population. Hence, moderate areas of plantation were established in many localities using the research results from the Department of Forest Research. The establishment strategy was solely through taungya. 
Table 1. South-western states and their land area.

\begin{tabular}{lccccc}
\hline State & $\begin{array}{c}\text { Total land } \\
\text { area }\left(\mathbf{k m}^{2}\right)\end{array}$ & $\begin{array}{c}\text { Number of forest } \\
\text { reserve }\end{array}$ & $\begin{array}{c}\text { Area of forest } \\
\text { reserves } \mathbf{( H a )}\end{array}$ & $\begin{array}{c}\text { Number of local } \\
\text { government area }\end{array}$ & $\begin{array}{c}\text { Forest reserve and } \\
\text { land area ratio (\%) }\end{array}$ \\
\hline Osun & 9,491 & 11 & 91,268 & 30 & 9.62 \\
Ondo/Ekiti & 20,451 & 37 & 305,541 & 17 and 16 & 14.94 \\
Ogun & 16,086 & 9 & 275,362 & 20 & 17.12 \\
Oyo & 27,848 & 18 & 169,173 & 33 & 6.06 \\
Lagos & 3,939 & 03 & 6,873 & 20 & 0.30 \\
\hline
\end{tabular}

Source: (FORMECU, 1998).



Figure 1. Map of Nigeria showing the study areas.

\section{MATERIALS AND METHODS}

Secondary data were collected from the State Forestry Departments in South- Western Nigeria. The information was based on forest regeneration between 1988 and 2004 as indicated in 1988 national forest policy.

\section{Study area}

The study area was south-western Nigeria which consists of Lagos, Ogun, Oyo, Osun, Ondo and Ekiti states. It is also known as the south west geographical zone of Nigeria. The area lies between longitude $2^{\circ} 31^{1}$ and $6^{\circ} 00^{1}$ East and Latitude $6^{\circ} 21^{1}$ and $8^{\circ} 37^{1} \mathrm{~N}$ (Agboola, 1979) with a total land area of $77,818 \mathrm{~km}^{2}$ and a projected population of 28, 767, 752 in 2002 (NPC, 1991). The study area is bounded in the East by Edo and Delta states, in the North by Kwara and Kogi states, in the West by the Republic of
Benin and in the south by the Gulf of Guinea. The study area had 85 constituted forest reserves with a forest area cover of 842,499 ha (Table 1).

\section{Climate and vegetation of the study area}

The climate of southwestern Nigeria is tropical in nature and it is characterized by wet and dry seasons. The temperature ranged between 21 and $34^{\circ} \mathrm{C}$ while the annual rainfall ranged between 150 and $3000 \mathrm{~mm}$. The wet season is associated with the Southwest monsoon wind from the Atlantic Ocean while the dry season is associated with the northeast trade wind from the Sahara desert. The vegetation in Southwest Nigeria is made up of fresh water swamp and mangrove forest at the belt. The low land in the forest stretches inland to Ogun and part of Ondo State, while secondary forest is towards the northern boundary where the derived southern Savannah exists (Agboola, 1979) (Figure 1). 


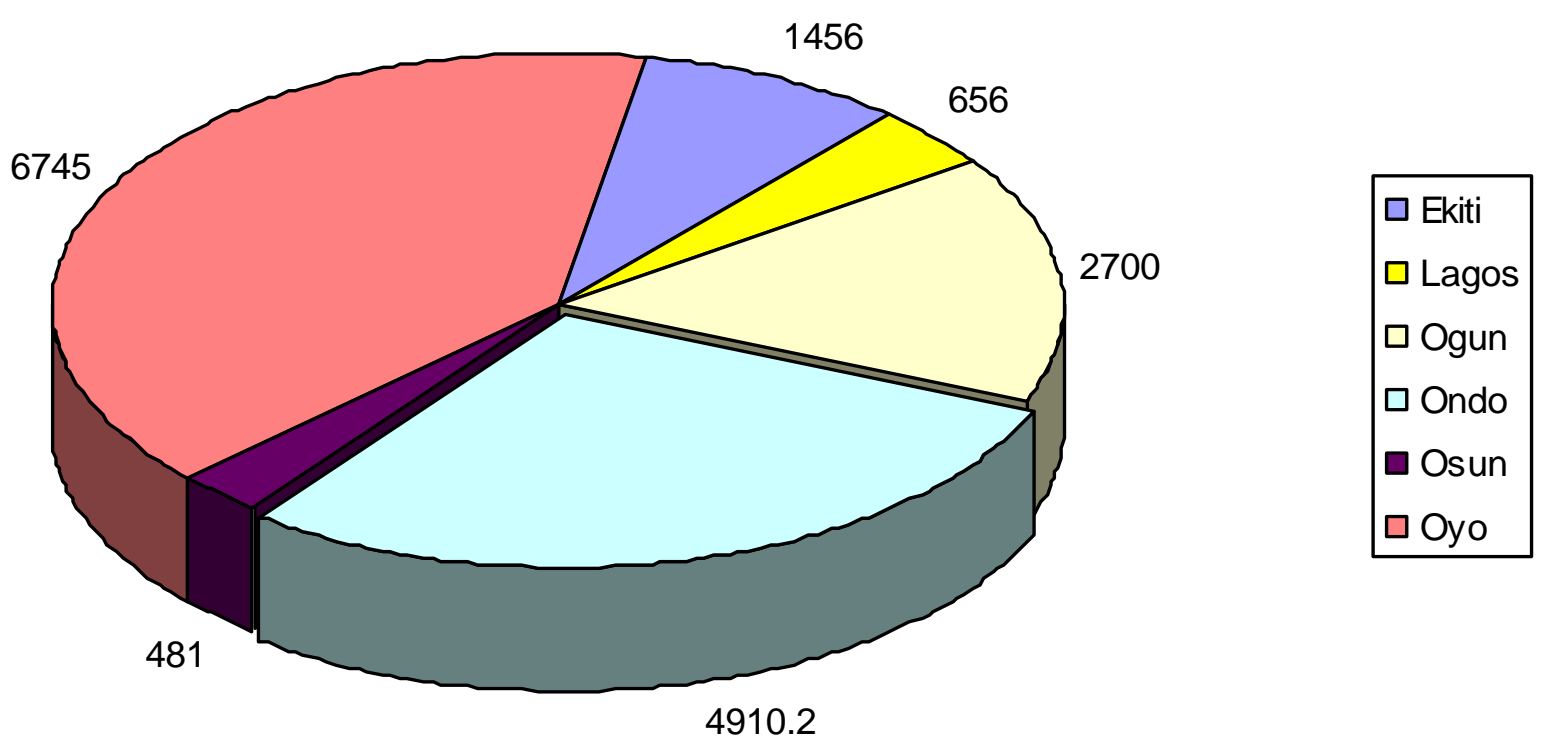

Figure 2. Distribution of forest regeneration (1988-2004) in the South-West. Source: Departments of Forestry the in South-Western Nigeria (2005).

\section{Data analysis}

The information gathered were analyzed using simple descriptive statistics such as frequencies and pie chart.

\section{RESULTS AND DISCUSSION}

\section{Forest regeneration between 1988 and 2004 in the South-West}

Figure 2 shows that there are a total of 1619.19 ha of forest regeneration between 1988 and 2004 in the southwest Nigeria. The largest was in Oyo State with an area of 6745 ha followed by Ondo State with 4910.27 ha. Others were Ogun State (2700 ha), Ekiti State (1456 ha), Lagos State, 656 ha and the least Osun, State with 481 ha.

\section{Conclusion}

Unless there is regeneration and sustained yield to equate harvest, the depletion rates of the forest are bound to continue with adverse consequences on the environment. Sustainable forest management is essential for guaranteed supply of goods and services. Forest exploitations today are guided by state revenue targets as against the principle of sustained yield. These have resulted in indiscriminate and over exploitation of forest resources culminating in serious resources depletion and degradation.

\section{RECOMMENDATION}

The expansion of planted forest and the use of agricultural tree crops for timber may reduce timberdemand pressure on the natural forest by supplying an increasing proportion of wood production. The use of incentives could attract the masses to engage in forest regeneration.

\section{REFERENCES}

Adeyoju SK (2001). Forestry for National Development: A critique of the Nigerian Situation. Forestry and National Development. (Ed: Popoola, L; Abu, J.E. and Oni P.I.). In the proceedings of the $27^{\text {th }}$ Annual in the proceedings of the conference of Forestry Association of Nigeria ueled in Abuja, FCT, Pp. 55-67.

Adeyoju SK (1991). Policy Formulation and Execution: Conflicts and Resolutions. An Invited Paper for the Advanced Course in Forestry Administration. pp. 22.

Agboola SA (1979). An Agricultural Atlas of Nigeria, Oxford University Press, Nigeria. P. 248.

Diouf J (1997). Forests for Sustainable Development: Towards the $21^{\text {st }}$ Century. A Speech Presented at the $\mathrm{x} 1$ World Forestry Congress. Antalya, Turkey Proceedings Vol. 7

FORMECU (1998). Forest Resource Survey, Geomatics, Nigeria Ltd, Abuja.

NPC (1991). National Population Commission 1991, Abuja, Nigeria. 